Pre-print manuscript

Published as:

Esther F.J.C. van Ginneken, Hanneke Palmen, Anouk Q. Bosma, Paul Nieuwbeerta, Maria L. Berghuis, (2018) "The Life in Custody Study: the quality of prison life in Dutch prison regimes", Journal of Criminological Research, Policy and Practice, https://doi.org/10.1108/JCRPP-07-2018-0020 


\section{The Life in Custody Study: The quality of prison life in Dutch prison regimes}

Esther F.J.C. van Ginneken*, Hanneke Palmen, Anouk Q. Bosma, Paul Nieuwbeerta and Maria L. Berghuis

Institute of Criminal Law and Criminology, Leiden University, the Netherlands

*Corresponding author:

Institute of Criminal Law and Criminology

P.O. Box 9520

2300 RA Leiden

The Netherlands

Tel: +31 (0)71 5272827

E-mail: e.f.j.c.van.ginneken@law.leidenuniv.nl 


\section{Funding}

This Life in Custody study was funded by the Dutch Prison Service (DJI) and Leiden University. The opinions, findings, and conclusions expressed in this article are those of the authors and do not necessarily reflect those of the DJI. The authors wish to thank the DJI for their support with the administration of the survey. 


\begin{abstract}
Purpose The Life in Custody study is a nationwide prospective cohort study examining the quality of prison life in the Netherlands. This paper describes Dutch prisoners' perceptions of prison climate, as well as differences across regimes.
\end{abstract}

Methods The target population of the study consisted of all male and female adult prisoners in the Netherlands who were incarcerated in various regimes in a total of 28 prisons, between January and April 2017. An intensive and personal recruitment strategy was employed. Participants completed a detailed survey, the Prison Climate Questionnaire (PCQ). Selfreported information on a variety of topics was collected, including perceived prison climate, well-being and self-reported behaviour.

Findings In total, 4,938 prisoners participated in the survey, which amounts to a high response rate of $81 \%$. Analyses show that respondents' characteristics are almost identical to those of non-respondents. Ratings of prison climate vary across domains and regimes, with more positive scores for minimum-security and extra-care regimes.

Value Findings of the Life in Custody study illustrate the value of having data on prison climate. Results of the study will contribute to more knowledge on imprisonment and what can be done to improve the humane treatment of offenders by the criminal justice system. Moreover, knowledge about the methodology of the study may enable future comparative research on prison climate.

Keywords: Imprisonment, Prison climate, The Netherlands, Quality of prison life, Well-being 


\section{The Life in Custody Study: The quality of prison life in Dutch prison regimes}

\section{Introduction}

Yearly, approximately 33,000 people enter prisons in the Netherlands (De Looff et al., 2017). In order to be able to minimise the harmful consequences of imprisonment, it is important to gather information about the conditions of confinement and its impact on the well-being and behaviour of prisoners. The Dutch Life in Custody (LIC) study was designed to fulfil this purpose and to systematically collect information on prison climate, its determinants, and its consequences. The study was developed for research and management purposes and therefore accommodated requests from the Dutch Prison Service as well as research interests for a new and unique study on prison climate in the Netherlands. The combined interest was a large benefit for this study, since it remains a challenge to conduct research on imprisonment. In particular, it can be difficult to achieve access to prisons for research purposes and to recruit a representative sample of participants. Furthermore, it is a challenge to address topics and research questions that are of interest to policy makers, practitioners and researchers. The Dutch Life in Custody study does precisely that. It has a methodologically strong design with a large population-based sample of all adult prisoners in Dutch facilities. The objectives of this article are: (1) to describe the Dutch prison population regarding their perceptions of the prison climate, and (2) to explore differences in perceptions of the prison climate across prisoners in different prison regimes. For this purpose, we used survey results from the Prison Climate Questionnaire, distributed among the population of adult prisoners in the Netherlands.

\section{Imprisonment in the Netherlands}

There is no uniform characterisation of imprisonment in the Netherlands. While conditions could be characterised as favourable given the low incarceration rate and interest in a positive prison climate, the government has introduced various austerity measures and a differentiation in privilege levels. Prisons in the Netherlands have recently received media attention due to the rather unusual situation of empty cells and prisons, and a falling prison population (Ash, 2016; Cluskey, 2017). Despite a spike in the imprisonment rate in 2005, the rate of imprisonment in the Netherlands remains comparatively low at 51 per 100,000 inhabitants 
(Aebi et al., 2018). The recent drop in the prison population has been accompanied by a range of budget cuts, including the closure of many prisons and an increase in double cell capacity from 2,200 (number of beds) in 2012 to 6,058 in 2016. Notwithstanding these austerity measures, the Prison Service has expressed a commitment to a humane and positive prison climate, which provided the impetus for a study into the quality of life in Dutch prisons.

A few important regime characteristics and recent policy changes are important to note in relation to the prison climate. First, Dutch prisons run different regimes for adults (young people under 18 are not included in the current study, but see Van der Laan and Eichelsheim, 2013). There are remand centres for pre-trial detainees and police detainees, regular prisons for convicted prisoners, and separate facilities for men and women. There are extra-care units within prisons for vulnerable prisoners, which may be due to the nature of their offence or mental health problems. Prisoners with severe mental health problems are imprisoned in psychiatric penitentiary facilities (not included in this study). There are also units for prisoners who received a measure of two-year imprisonment for persistent offenders (ISD, see Moerings, 2007). Variation exists in the security level of units: a few units have extra security measures (e.g. for known or suspected terrorists, other high-risk prisoners, and prisoners with severe behavioural problems) and prisons have segregation cells; there are also minimumsecurity units, with more freedom and sometimes only night-time imprisonment. There is one prison for foreign national prisoners (not included in this study).

Secondly, in 2014 a differentiation in regimes was introduced for convicted prisoners (Staatscourant 20 februari 2014). The basic regime applies to all prisoners (including pre-trial detainees) and provides for 43 hours of out-of-cell time and activities (including one hour for visits) per week. Convicted prisoners can be promoted to a 'plus' regime if they have shown good behaviour and a motivation to work on their re-integration for a period of six weeks. The plus regime offers five extra hours a week of out-of-cell activities, including education, an extra hour for visits, and rehabilitation courses. Furthermore, prisoners in the plus regime are normally allowed to stay out of cell during activities and they are also eligible for placement in minimum-security facilities at the end of their sentence. Misconduct can result in demotion to the basic regime. The introduction of regime differentiation was intended to positively influence prisoners' behaviour by rewarding desirable behaviour and to reserve costly reintegration activities for motivated prisoners.

Lastly, various experimental changes to prison conditions have been introduced in different prisons under the umbrella of prison climate. Prisoner who are affected by these changes tend to have greater freedom, for example in terms of moving around the prison, 
having a key to their own cell, and the ability to cook their own meals. These initiatives tend to be small-scale and available exclusively to prisoners in a 'plus' regime. The evaluations from these projects have so far found some support for positive effects on the prison climate, including staff-prisoner relationships and prisoners’ autonomy (De Jong, Willems and Van Burik, 2015; De Jong, Willems and Torregrosa, 2016; Farahi and Van de Rijt, 2016).

\section{Prison climate}

Prison climate is the central concept in the Life in Custody study's theoretical framework and is similar to notions such as subjective quality of prison life. Prison climate has been defined as 'the social, emotional, organizational and physical characteristics of a correctional institution as perceived by inmates and staff' (Ross et al., 2008, p. 447). A positive prison climate is expected to contribute to superior outcomes in terms of well-being, prisoner behaviour, treatment motivation, and therapeutic change (Gonçalves et al., 2016; Goomany and Dickinson, 2015; Ruiz, 2007; Van der Helm et al., 2011, 2014; Woessner and Schwedler, 2014; Wright, 1993). As reflected in the definition, prison climate is regarded as a multidimensional construct. In an extensive literature review on prison climate and existent measures, the following dimensions were identified as factors contributing to prison climate: autonomy, safety and order, meaningful activities, relationships between prisoners and with staff, contact with the outside world, and facilities (Boone et al., 2016). Based on this literature review, the first version of the Prison Climate Questionnaire (PCQ) was developed (Beijersbergen, 2016). Following a pilot study, a few small adjustments were made (e.g. phrasing of questions, addition of a few scales to meet research interests) to the PCQ as used in the present study. The PCQ meets a need for a comprehensive, reliable and valid assessment of prison climate, because previous questionnaires either assess only limited dimensions (e.g. only social climate), or have not been sufficiently validated (Boone et al., 2016; Tonkin, 2016). The PCQ incorporates valid scales from earlier Dutch prisoner surveys in addition to other, sometimes slightly adjusted, scales that correspond to relevant constructs identified through the extensive literature study. A further strength of the PCQ is that its psychometric properties have been well examined, and that it has been determined a reliable and valid assessment of prison climate (Beijersbergen, 2016; Bosma et al., submitted for publication). Each of the prison climate dimensions will be briefly discussed in turn to show how and why they are related to the experience of imprisonment, how they are related to each other, and how they are expected to be related to prisoner well-being and behaviour. 


\section{Autonomy}

Autonomy is recognised as a fundamental human need (Ryan and Deci, 2000) and the deprivation of autonomy that imprisonment inevitably imposes is therefore not surprisingly considered a pain of imprisonment (Sykes, 1958). There are various organisational features that can result in more or less autonomy in prison. In general, higher security levels of imprisonment tend to be associated with greater autonomy restrictions, but there is also variation in terms of whether prisoners share a cell, have a key to their cell and have a say in their daily activities. Greater autonomy is generally associated with higher perceived quality of prison life (De Jong, Willems and Van Burik, 2015; Van der Kaap-Deeder et al., 2017), although very little research has been conducted on prisoners' perceived autonomy and its relationship with well-being and post-prison outcomes. Yet, it should be noted that greater freedom can also be accompanied by behavioural expectations, temptations and uncertainty, which may be experienced as painful (Shammas, 2014; Crewe, 2011). Nonetheless, greater autonomy is likely to be less harmful, particularly with an eye on life after imprisonment (De Vos and Gilbert, 2017).

\section{Safety and order}

Maintaining a safe environment for staff and prisoners is a key task for prison governors. Experiences of violence and fear of victimisation in prison are associated with diminished well-being (Wooldredge, 1999; McCorkle, 1993; Baidawi et al., 2016). Safety is not merely a function of the security measures imposed in prison. In fact, higher security may even have a criminogenic effect. Experimental evidence shows that prisoners with similar risk classifications who were randomly placed in low and high security prisons had a higher likelihood of returning to prison when placed in a high security prison (Gaes and Camp, 2009). Other research and review studies have identified various contextual predictors of misconduct and violence, including a lack of staff experience, poor prison management, limited programme availability, prison size, and composition of the population (Gadon et al., 2006; Gendreau et al., 1997; Gonçalves et al., 2014). Safety and order are also partly influenced by the nature and quality of relationships in prison.

\section{Relationships in prison}

Staff-prisoner relationships are considered a key determinant of the quality of prison life. This is not surprising, given the dependence of prisoners on staff for obtaining basic goods and 
services in the prison. Prisoners' privileges and even their autonomy are negotiated in the daily interaction with staff. Good staff-prisoner relationships are also in the interest of staff, as they are considered crucial to maintaining a safe and orderly environment (Sykes, 1958; Sparks et al., 1996; Crewe et al., 2015; Liebling, 2004, 2011; Molleman and Leeuw, 2012). However, highly-rated relationships between staff and prisoners are not necessarily an indicator of safety: if prison officers are too reluctant to use their authority, this may result in unsafe situations, where prisoners are in control more so than the officers (Crewe et al., 2015; Liebling, 2011). 'Right' staff-prisoner relationships are characterised by respect and fair and confident use of authority, so that (vulnerable) prisoners are protected from victimisation and exploitation. Prisoner relationships are also important in this respect, as a power vacuum resulting from too little staff control may be filled by prisoners (Jacobs, 1977). Recent research has found that social relationships among prisoners resemble friendship networks in non-prison settings (Schaefer et al., 2017). There are mixed findings on the contribution of peer trust in prison to well-being (Kreager et al., 2016; Lindquist, 2000; Kruttschnitt and Gartner, 2005). Previous research has identified staff-prisoner relationships in Dutch prisons as supportive and fair (Dirkzwager and Kruttschnitt, 2012), with a discernible positive impact on prisoner well-being, behaviour and even outcomes after release (Beijersbergen et al., 2014, 2015, 2016).

\section{Meaningful activities}

Participating in activities in prison can relieve some of the boredom and help prisoners pass the time (Gonçalves et al., 2015; Yang et al., 2009). In some instances, activities may even be experienced as meaningful and potentially useful after release. Some jobs in prison may be considered meaningful where prisoners develop skills and are given responsibilities, including more freedom to move around the prison (De Jong et al., 2015; De Jong et al., 2016; Stevens, 2012). Helping other prisoners, for example as 'listener', can be used as opportunity for growth and giving back (Van Ginneken, 2016). Other meaningful activities may be creative in nature, which may be a way to maintain (or reconstruct) a sense of identity, exercise peaceful resistance to the loss of autonomy, and cope with trauma (Digard and Liebling, 2012; Cox and Gelsthorpe, 2012; Cheliotis, 2012). Some prisoners also find meaning in religious services or sports (Maruna et al., 2006; Martos-García et al., 2009).

\section{Contact with the outside world}


Separation from loved ones is one of the most painful aspects of imprisonment. Contact through phone and visits its often strictly regulated and monitored. There is variation among prisons, however, in the accessibility and nature of opportunities for contact with friends and family. Substantial country differences can be observed (Beyens and Boone, 2013), but also differences within countries (Hutton, 2016). Visits and other forms of contact can provide emotional support and mitigate the pains of separation. It also allows for maintenance (albeit minimal) of the role of mother or father for prisoners with children; facilities for family visits are also very diverse and can influence the quality of prison life. Two further considerations are important here: firstly, imprisonment not only negatively affects prisoners, it can have detrimental emotional and financial effects for family and friends outside. The quality of prison life, then, matters not only to prisoners, but also to their loved ones. Secondly, visits are not a universally positive experience; some prisoners choose not to have visits, because they consider them a source of distress, rather than emotional relief (Pleggenkuhle et al., 2018).

\section{Facilities}

This final 'facilities' dimension of prison climate encompasses general facilities and amenities, physical conditions, and health care facilities in the prison. Boone et al. (2016) consider food quality and exercise facilities of particular importance, but quality of health care is also a contributing factor. The availability of facilities overlaps with autonomy, in the sense that the opportunity for self-catering increases autonomy as well as, potentially, the quality of prisoners' nutrition. Similarly, exercise facilities promote physical health and can also make a positive contribution to meaningful activities in prison (Meek and Lewis, 2012).

\section{Current study}

The literature review presented above has identified that contextual characteristics, captured by the multidimensional construct 'prison climate', can play an important role in prisoner adjustment. The present study gives insight in perceptions of prison climate in Dutch prisons based on a nation-wide survey and examines differences across regimes: regular prison regimes, pre-trial detention, police detention, extra-care regimes, regimes for persistent offenders, and minimum security regimes. Based on previous research that has identified staff-prisoner relationships in the Netherlands as good, it is expected that prisoners report higher scores on the interpersonal dimensions (i.e. safety and order, relationships in prison, and contact with the outside world) of prison climate than on the material and organisational 
dimensions (meaningful activities, autonomy, and facilities). So far, little is known about regime differences in relation to prison climate, although we expect that these will be related in particular to the availability of activities, freedom of movement, staff involvement, and characteristics of the population (e.g. stage of incarceration, particular needs). It is expected that regular prison regimes are regarded more positively than pre-trial detention, police detention and regimes for persistent offenders, while minimum security and extra-care regimes are regarded most positively overall.

\section{Methodology}

\section{Dutch Life in Custody Study}

The Dutch Life in Custody study was designed to measure the quality of prison life in the Netherlands. The aim was to administer the survey to the full population of pre-trial detainees and prisoners, housed in 28 prisons in the Netherlands, in the period of January to April 2017.[1] Uniquely, the Dutch Life in Custody study is a nationwide prospective cohort study of quality of life in prisons, in which both male and female prisoners participated, in various phases of punishment (pre-trial and convicted prisoners), and in regimes that vary in security level (from minimum to regular security) and target population (regular regimes, terrorist regimes, regimes for persistent offenders, and extra care units).

\section{Sample participants}

In total, 7,109 prisoners were held in pre-trial detention and prison during the weeks of data collection. Of those, 6,088 prisoners (86\%) were invited to participate in our project (548 could not be reached primarily because they were released in the week of data collection; 473 could not be invited due to language difficulties, severe mental health problems or being placed in isolation in the week of the data collection). Of the 6,088 invited prisoners, 4,938 agreed to participate in our survey study. The survey was independently carried out by a University team and achieved a very high response rate of 81\%. Main reasons for nonparticipation were 'don't want to' and lack of trust in scientific research. All participants were asked informed consent to collect and use administrative data; 400 participants did not give consent and participated anonymously. We have survey and administrative data for a sample of 4,538 prisoners (see Figure 1).

[Figure 1 about here] 


\section{Data collection procedure and recruitment strategy}

In order to be able to say anything meaningful about prison climate, it is very important to elicit participation of a representative group of prisoners. Typically, prison survey research has achieved response rates between 4\% and 53\% (Gojkovic et al., 2011; McDougall et al., 2017; Molleman and Leeuw, 2012). Through employing an intensive and personal recruitment strategy, we achieved a response rate of $81 \%$. The strategy used in the Life in Custody study involved three important phases: (1) preparation and promotion; (2) personal and independent recruitment; and (3) confidential collection of questionnaires.

(1) Preparation and promotion

Prior to the data collection, we sent a letter to each prison to announce the data collection and to ask for the appointment of a liaison contact, who would be responsible for facilitating the project within the prison. For prisons, facilitating the survey was mandated by the Prison Service; for prisoners, participation was voluntary. We arranged meetings with each of the liaison contacts to introduce the on-site research team and go over the research project and procedures, discuss any possible practical difficulties, and agree on the best approach (including, for example, the arrangement of private rooms for assisting prisoners with filling out the questionnaires). This appointment was also used to meet with a representative of the prisoner committee to explain the study, its purpose and the importance of wide participation. Where possible, we shared improvements that had resulted from previous prisoner surveys. We also distributed promotional materials: flyers and posters to announce our upcoming visit among prisoners and prison staff. Staff members were further informed separately about the project through newsletters and staff meetings, and they were generally involved in designing an optimal schedule and strategy for visiting the units for recruiting participants.

Another important element of the preparation phase was the training of research assistants. The research assistants were mostly criminology master students or criminology graduates. They were given multiple training sessions on safety, research ethics, informed consent, and to practice explaining the study, motivating prisoners to participate, and handling difficult situations.

(2) Personal and independent recruitment

Data was collected between January and April 2017. Each prison (ranging from 25 - 430 prisoners each) was visited for a maximum of one week and, normally, four prisons were 
visited per week, by teams of 2-8 research assistants. The data collection period lasted 7 weeks.

During data collection, the research assistants received weekly lists of all prisoners housed in that particular prison at that moment. This enabled them to keep track of who they could invite and who they had already invited. Prior to visiting a unit, they discussed with members of staff if there were any prisoners they could not invite to take part, due to severe mental health problems, language difficulties, or because they were held in isolation.[2] In couples, research assistants personally invited each prisoner at the door of their cell. This was preferred over approaching prisoners in common rooms, which would have made them potentially vulnerable to group pressure.

As a conversation starter, researchers handed out a small incentive (e.g. snack or can of soda) to all prisoners (including non-participants), which earlier studies had found to increase motivation to participate (Beijersbergen, 2016; Sipma and Soutendijk, 2016), possibly by creating good-will. Although only of anecdotal value, one prison in our study did not provide an incentive and they had the lowest response rate.

An informed consent procedure was followed in line with current research ethics (British Society of Criminology, 2015). Prisoners received information about the aims of the research and they were told that they could, at any point, withdraw their contribution to this study. We made sure to emphasise that we were an external research partner, and we would never give insight in personal survey data to prison staff, police officers or other persons within the criminal justice system. When prisoners gave their permission for participating in the survey study, we also asked them permission to match their survey data with administrative data, such as their criminal records. Prisoners could also choose to fill out the survey anonymously, in which case it would only be used for reporting that would not require matching with administrative data. As can be seen from Figure 1, most prisoners gave permission for matching (92\%).

After consenting to participate, prisoners were handed a paper and pencil version of the questionnaire, in their language of preference (93\% Dutch, 6\% English, and 1\% Spanish). Prisoners were also given the opportunity to fill out the questionnaire with help of a research assistant (e.g., in case they had literacy or concentration problems).

(3) Confidential collection of questionnaires

Researchers made an appointment with the prisoners to collect the questionnaire one or two days later that week. When collecting the questionnaires, researchers were instructed to 
carefully check the questionnaires for forgotten parts, to avoid missing data as much as possible and to offer assistance if prisoners had difficulties filling out the questionnaire. While prisoners were kindly asked to fill out any forgotten parts of the questionnaire, research assistants were carefully instructed not to pressure prisoners to fill in parts of the questionnaire that they deliberately did not want to complete. Questionnaires were collected in sealed envelopes for each unit and these envelopes were stored in sealed boxes in a locked space, until the end of the data collection. Prisoners who did not hand in the questionnaire during the data collection week, were offered the opportunity to send the questionnaire to the University in an addressed and stamped envelope. Questionnaires were scanned by the research assistants using special software, which automatically converted scores to a digital dataset.

Finally, during data collection, senior researchers could be reached at any time to address questions or concerns from research assistants or the prison liaison contact. They also received a progress report at the end of each day from one of the research assistants in each prison, which allowed them to determine if additional research assistants were needed to help out in any of the prisons.

\section{Data and measures}

For the purpose of the Life in Custody study as a whole, we obtained (1) self-reported data on prison climate from a prisoner survey; (2) self-reported data on 'work climate' from a staff survey carried out by a third party; and (3) administrative data on institutional and regime characteristics, and further information about prisoners. In the present study we report only on the self-reported data on prison climate from the prisoner survey: the Prison Climate Questionnaire (PCQ).

The PCQ is an adaptation and extension of a questionnaire developed in an earlier pilot study (Beijersbergen, 2016). The new PCQ includes 136 items that measure 21 concepts, of which 12 scales cover the six prison climate domains described above (autonomy, safety, relationships in prison, meaningful activities, contact with the outside world, and facilities). Additionally, the PCQ includes single items on food quality, shop quality, the building and ability to self-cater, and an item that asks respondents to rate their overall satisfaction with the institution ('overall quality'). It also includes scales to measure potential correlates of prison climate, including psychological well-being, behaviour and victimisation, as well as scales that may potentially serve as control variables in research (e.g. having a partner, having 
children, level of education, and contact with friends and family prior to imprisonment). The prison climate scales are scored on a 5-point Likert scale (from strongly disagree [1] to strongly agree [5]). A higher score means a more positive perception, except for 'subjective sentence severity' (a potential correlate of prison climate), where a higher score means a more severely experienced sentence.

A more detailed description of the PCQ and its psychometric properties will be presented in a separate article (Bosma et al., submitted). For here, it suffices to mention that all scales have excellent psychometric properties, with reliability scores between .78 and .92 and good construct validity, supported by factor analysis and relevant correlations (see also Beijersbergen, 2016).[3]

\section{Results}

\section{Sample characteristics and representativeness}

Table 1 describes the characteristics of participants of the Life in Custody Study. The majority of participants were male (94.6\%), born in the Netherlands (65.3\%) and had a low education (56.1\%). Over a third of participants were incarcerated for a violent offence. The descriptive statistics also show that a fairly large proportion of participants was in pre-trial detention (38.1\%). Information on partners and children of prisoners is not systematically registered in most countries, including the Netherlands. We therefore asked this from participants in the survey and found that 59.6\% of participants had at least one child, which is important information considering the impact imprisonment may have on families.

We checked the representativeness of our sample by comparing characteristics of participants who gave permission to use official registration data $(n=4,538)$ with those of non-participants $(n=2,284)$ using official registration data from the Dutch Prison Service, where available. No significant differences were found with respect to age, sex and time served. Participants were more likely to be born in the Netherlands than non-participants, $\chi^{2}(1, N=6,704)=81.23, p<.001$, which may be due to the fact that the surveys were available only in Dutch, English and Spanish. It is also possible that native Dutch participants were simply more willing to participate. In relation to index offence, property offenders were slightly under-represented in the sample, while drugs offenders were slightly overrepresented, $\chi^{2}(4, N=5,802)=23.79, p<.001$. Finally, pre-trial detainees were overrepresented while regular prisoners were underrepresented, which may be partially explained by the exclusion of one prison wing from participation due to its very recent opening. Overall, 
given the very large sample size and reasonable representation of different groups of the prison population, the survey results are generalizable to the Dutch population of adult prisoners in regular and remand prisons (excluding prisoners in foreign national prisons and psychiatric prisons).

[Table 1 about here]

\section{Overall quality of prison life}

Figure 2 and Table 2 describe the scores on the survey for the total sample, as well as for the different regimes. Overall, the results indicate that prisoners are, on average, fairly positive about safety and relationships with other prisoners and staff. In contrast, autonomy, the availability of meaningful activities and most facilities in prison are rated below 3 on average (on a 5-point Likert scale), which indicates a negative judgement. Food quality, which is considered part of the facilities dimension, is rated most negatively $(M=2.02)$.

Finally, we present results on how prison climate differs across prison regimes. We do this by first comparing pre-trial and regular prison regimes, and subsequently by comparing other regimes, i.e. police detainees, extra-care, persistent offenders and minimum-security.[4]

[Figure 2 about here]

[Table 2 about here]

\section{Pre-trial and regular prison regimes}

The superscript letters in Table 2 indicate significant differences $(\alpha<0.5)$ between regimes. Regular prison regimes and pre-trial detention make up the largest groups in Dutch prisons. Overall, participants in prison regimes report somewhat higher scores than participants in pretrial detention on most domains of prison climate, although most effect sizes are small $(d<$ $0.5)$ [5], with the exception of the ability to self-cater $(d=0.97)$. Participants in regular prison regimes report more autonomy $(d=0.31)$ and greater satisfaction with activities $(d=0.20)$ and the availability of meaningful activities $(d=0.27)$. They are also more positive about visits $(d=0.33)$ and the frequency of contact with family and friends $(d=0.24)$. The overall quality of prison regimes is rated higher than the quality of pre-trial detention $(d=0.19)$. Finally, participants in regular prison regimes report greater subjective well-being $(d=0.23)$, lower subjective sentence severity $(d=-0.12)$ and better psychological health $(d=0.19)$. 
Other regimes: Police detainees, extra-care, persistent offenders and minimum-security Prisoners in minimum-security regimes are most positive about the quality of prison life and also score higher on measures of well-being. The differences are particularly pronounced in comparison with pre-trial detention, police detention and persistent offender regimes, with Cohen's $d$ s for overall quality of $0.67,0.88$ and 0.78 , respectively, indicating medium to large effects. Prisoners in minimum-security regimes report much greater autonomy than prisoners in each of the other regimes, with Cohen's $d$ s ranging from 0.60 (vs. extra-care) to 1.07 (vs. police detainees). Prisoners in extra-care regimes tend to rate the quality of prison life more positively, but experience lower psychological health and well-being. They also report the highest subjective sentence severity, followed by prisoners in pre-trial detention. Police detainees are least satisfied with meaningful activities and contact with the outside world, and experience the lowest level of autonomy, followed by pre-trial detainees. Finally, it is noteworthy that prisoners in extra-care regimes feel less safe than prisoners in other regimes (except persistent offenders). This is consistent with the finding that a comparatively high proportion of prisoners in this regime reported victimisation (43.9\%) in the past two months. In persistent offender regimes, prisoners reported the highest rates of misconduct (48.5\%) and victimisation (45.5\%). However, the proportion of prisoners who report incidences of discrimination, misconduct and victimisation may be also (at least partly) be a function of time served: police detainees ( $M=2$ months) and pre-trial prisoners ( $M=3$ months) are likely to have spent less time in prison than prisoners in regular prison units ( $M=17$ months) and units for persistent offenders $(M=16$ months $)$.

\section{Discussion}

This article reported on the main descriptive results of the Life in Custody Study, which gives an insight in the prison climate in the different regimes in Dutch prisons. Overall, safety, staff-prisoner relationships and prisoner relationships were rated fairly positively, which was consistent with expectations and previous research (Dirkzwager and Kruttschnitt, 2012). Prisoners were dissatisfied with their material conditions, particularly the availability of meaningful activities. In line with our hypothesis, ratings of the different domains of prison climate were particularly positive for minimum-security and extra-care regimes. Minimum security regimes are known to allow more freedom of movement to prisoners; some prisoners even have the ability to work outside the prison. Extra-care regimes tend to be smaller in size, 
with closer staff supervision (and likely more opportunities for staff-prisoner interactions). The relatively low scores on psychological health and well-being among prisoners in extracare regimes may be explained by characteristics of the target population: prisoners who are considered vulnerable due to the nature of their index offence or mental health needs. It is noteworthy that pre-trial detainees experienced high subjective sentence severity, even though they had not yet received a final sentence. This may be partly explained by uncertainty and stress associated with detention prior to sentencing; previous research has identified pre-trial detention as a very stressful period of imprisonment (Fazel et al., 2008; Liebling and Ludlow, 2016). Low scores for police detention and pre-trial detention may also be explained by less extensive programming and more hours spent in-cell (prisoners in these regimes are incarcerated under 'basic regime’ conditions; the ‘plus regime' only becomes available for convicted prisoners). Finally, the results raise some concern over the safety of prisoners in persistent offender regimes, where rates of self-reported victimisation and misconduct were relatively high. This may have a negative impact on prisoner and staff well-being (Wooldredge, 1999; McCorkle, 1993; Baidawi et al., 2016). In sum, prisons in the Netherlands appear decent in terms of interpersonal treatment, but are perceived by prisoners as lacking with respect to activities they offer, which could have implications for prisoner well-being, as well as their preparation for release.

The study has a few notable strengths. First, the project has benefited from a collaboration between the Dutch Prison Service, who facilitated access to all prisons, and Leiden University, who were responsible for confidential treatment and independent analysis of data. An intensive data collection strategy was employed to maximise the response. As a result, the study includes a largely representative sample of male and female prisoners across different prison regimes. Secondly, the instrument used to measure prison climate was developed on the basis of an extensive literature review and pilot study and can be assumed to be valid and reliable. It is also a comprehensive instrument in the sense that it assesses prison climate across six different dimensions. The results show that there are observable differences in the scores on each of these dimensions and they allow for meaningful comparisons across regimes.

A few limitations about the study should also be noted. First, non-Dutch prisoners are under-represented in the study. This may be due to language difficulties, which could perhaps be remedied in the future with making questionnaires available in other languages, such as French and Arabic. Secondly, the current study did not include a qualitative element in the research. Interviews, observations and focus groups could benefit interpretation of the 
findings, for example by asking prisoners in different regimes about activities they enjoy or consider to be lacking. This would be especially helpful given that prisoners may see the survey as an opportunity to advance their material circumstances. Finally, some of the most vulnerable prisoners were excluded from the research due to severe mental health problems, which raised concerns about their own safety, ability to give informed consent, and safety of the researchers. Nevertheless, their experience in prison may be unique and is just as important to consider - it is therefore worthwhile to think of ways that they may be given a chance to participate in future studies.

The collected data enables further research into prison climate, its determinants, and its consequences. We have developed a research programme in which we will look at, on the one hand, the determinants of prison climate, including regime and institutional characteristics, prisoner characteristics and staff culture; and on the other hand, the relationship between prison climate, prisoner well-being, misconduct in prison, and recidivism. Other researchers are encouraged to use the instrument in other countries and adapt it to the local context, which would enable comparative research on prison climate. It would also be worthwhile to know whether changes to prison conditions result in measurable changes on dimensions of prison climate, which can be investigated with longitudinal studies.

\section{Notes}

[1] Prisoners in psychiatric institutions and immigration detention were not targeted in this study, because many questions in the survey did not apply and they were expected to need a different approach due to mental health problems and language difficulties.

[2] Inevitably, during data collection weeks, prison populations somewhat fluctuated, with some new prisoners entering the prison facility and others being released or being transferred to another prison. New prisoners, although not on the initial list, were invited for research; transferred prisoners, where possible, were invited to participate in their new prison.

[3] A copy of the questionnaire can be requested from the authors.

[4] In order to compare regimes in terms of prison climate, we conducted one-way ANOVA tests, followed by post-hoc pairwise comparisons (with Bonferroni correction for multiple testing).

[5] As a rule-of-thumb, Cohen (1992) suggested that effect sizes of 0.2, 0.5 and 0.8 indicate small, medium and large effects, respectively. Effect sizes convey information about the magnitude of the difference, rather than the statistical significance. 


\section{References}

Aebi, M.F., Tiago, M.M., Berger-Kolopp, L. and Burkhardt, C. (2018), Council of Europe annual penal statistics. SPACE I - Prison populations, Council of Europe, Strasbourg.

Ash, L. (2016), “The Dutch prison crisis: A shortage of prisoners”, BBC News Magazine, available at: http://www.bbc.com/news/magazine-37904263 (accessed 3 May 2018).

Baidawi, S., Trotter, C. and Flynn, C. (2016), "Prison experiences and psychological distress among older inmates”, Journal of Gerontological Social Work, Vol. 59 No. 3, pp. 252270.

Beijersbergen, K.A., Dirkzwager, A.J., Eichelsheim, V.I., Van der Laan, P.H. and Nieuwbeerta, P. (2014), “Procedural justice and prisoners' mental health problems: A longitudinal study”, Criminal Behaviour and Mental Health, Vol. 24 No. 2, pp. 100112.

Beijersbergen, K.A., Dirkzwager, A.J., Eichelsheim, V.I., Van der Laan, P.H. and Nieuwbeerta, P. (2015), “Procedural justice, anger, and prisoners’ misconduct: A longitudinal study”, Criminal Justice and Behavior, Vol. 42 No. 2, pp. 196-218.

Beijersbergen, K.A., Dirkzwager, A.J. and Nieuwbeerta, P. (2016), “Reoffending after release: Does procedural justice during imprisonment matter?”, Criminal Justice and Behavior, Vol. 43 No. 1, pp. 63-82.

Beijersbergen, K.A. (2016) Ontwikkeling van de Leefklimaat Vragenlijst Penitentiaire Inrichtingen, DJI, Den Haag.

Beijersbergen, K.A., Dirkzwager, A.J., Van der Laan, P.H. and Nieuwbeerta, P. (2016), “A social building? Prison architecture and staff-prisoner relationships”, Crime \& Delinquency, Vol. 62 No. 7, pp. 843-874.

Beyens, K. and Boone, M. (2013), “'Zeg maar Henk tegen de chef'. Ervaringen met het Belgisch detentieregime in de PI Tilburg”, Boom Lemma, Den Haag.

Boone, M., Althoff, M. and Koenraadt, F. (2016), Het leefklimaat in justitiële inrichtingen, Boom juridisch, Den Haag.

Bosma, A.Q., Van Ginneken, E.F.J.C., Palmen, H., Pasma, A., Nieuwbeerta, P. and Beijersbergen, K.A. (submitted), “Measuring the quality of life in prison: The psychometric quality of the Prison Climate Questionnaire”.

British Society of Criminology (2015). Statement of ethics. Available at: http://www.britsoccrim.org/documents/BSCEthics2015.pdf (accessed 17 May 2018). 
Cheliotis, L.K. (2012), “The arts of imprisonment: An introduction”, in Cheliotis, L.K. (Ed.), The arts of imprisonment: Control, resistance and empowerment, Ashgate, Burlington, VT, pp. 1-26.

Cluskey, P. (2017), “Netherlands weighs up strange prison problem: Too few prisoners”, The Irish Times, available at: https://www.irishtimes.com/news/world/europe/netherlandsweighs-up-strange-prison-problem-too-few-prisoners-1.3291804 (accessed 3 May 2018).

Cohen, J. (1992). “A power primer”, Psychological Bulletin, Vol. 112 No. 1, pp. 155-159.

Cox, A. and Gelsthorpe, L. (2012), “Creative encounters: Whatever happened to the arts in prisons?” in Cheliotis, L.K. (Ed.), The Arts of Imprisonment: Control, Resistance and Empowerment, Ashgate, Burlington, VT, pp. 255-274.

Crewe, B. (2011), “Depth, weight, tightness: Revisiting the pains of imprisonment”, Punishment \& Society, Vol. 13 No. 5, pp. 509-529.

Crewe, B., Liebling, A. and Hulley, S. (2015), “Staff-prisoner relationships, staff professionalism, and the use of authority in public-and private-sector prisons”, Law \& Social Inquiry, Vol. 40 No. 2, pp. 309-344.

De Jong, B.J., Willems, P.J.H. and Torregrosa, L.D.R. (2016), Zelfredzaamheid in detentie: Evaluatie van de pilot Participerende Detentie \& Maatschappelijke Arbeid PI Nieuwersluis, VanMontfoort, Woerden.

De Jong, B.J., Willems, P.J.H. and Van Burik, A.E. (2015), Evaluatie pilots zelfredzaamheid gedetineerden, VanMontfoort, Woerden.

De Looff, J., Van de Haar, M., Van Gemmert, N. and Valstar, H. (2017), DJI in getal 20122016, DJI, Den Haag.

De Vos, H. and Gilbert, E. (2017), “Freedom, so close but yet so far: The impact of the ongoing confrontation with freedom on the perceived severity of punishment”, European Journal of Probation, Vol. 9 No. 2, pp. 132-148.

Digard, L. and Liebling, A. (2012), “Harmony behind bars: Evaluating the therapeutic potential of a prison-based music programme”, in Cheliotis, L.K. (Ed.), The arts of imprisonment: Control, resistance and empowerment, Ashgate, Burlington, VT, pp. 275-300.

Dirkzwager, A.J. and Kruttschnitt, C. (2012), “Prisoners’ perceptions of correctional officers' behavior in English and Dutch prisons”, Journal of Criminal Justice, Vol. 40 No. 5, pp. 404-412. 
Farahi, C. and Van de Rijt, J. (2016), “Normalisatie en zelfredzaamheid binnen het gevangeniswezen”, Proces, Vol. 95 No. 2, pp. 75-85.

Fazel, S., Cartwright, J., Norman-Nott, A. and Hawton, K. (2008), “Suicide in prisoners: A systematic review of risk factors”, The Journal of Clinical Psychiatry, Vol. 69 No. 11, pp. 1721-1731.

Gadon, L., Johnstone, L. and Cooke, D. (2006), “Situational variables and institutional violence: A systematic review of the literature”, Clinical Psychology Review, Vol. 26 No. 5, pp. 515-534.

Gaes, G. G. and Camp, S. D. (2009), “Unintended consequences: Experimental evidence for the criminogenic effect of prison security level placement on post-release recidivism”, Journal of Experimental Criminology, Vol. 5 No. 2, pp. 139-162.

Gendreau, P., Goggin, C.E. and Law, M.A. (1997), "Predicting prison misconducts”, Criminal Justice and Behavior, Vol. 24 No. 4, pp. 414-431.

Gojkovic, D., Meek, R. and Mills, A. (2011), Offender engagement with third sector organisations: A national prison-based survey (Working paper 61), Third Sector Research Centre, Birmingham.

Gonçalves, L.C., Endrass, J., Rossegger, A. and Dirkzwager, A.J.E. (2016), “A longitudinal study of mental health symptoms in young prisoners: Exploring the influence of personal factors and the correctional climate”, BMC Psychiatry, Vol. 16 No. 1, pp. 1929.

Gonçalves, L.C., Gonçalves, R.A., Martins, C. and Dirkzwager, A.J.E. (2014), “Predicting infractions and health care utilization in prison: A meta-analysis”, Criminal Justice and Behavior, Vol. 41 No. 8, pp. 921-942.

Gonçalves, L.C., Gonçalves, R.A., Martins, C., Braga, T., Ferreira, C., Lindegaard, M.R., and Dirkzwager, A.J.E. (2015), “Prisoners’ coping strategies in Portugal”, in Reeves, C. (Ed.), Experiencing imprisonment: Research on the experience of living and working in carceral institutions, Routledge, London, pp. 119-136.

Goomany, A. and Dickinson, T. (2015), “The influence of prison climate on the mental health of adult prisoners: A literature review”, Journal of Psychiatric and Mental Health Nursing, Vol. 22 No. 6, pp. 413-422.

Hutton, M. (2016), “Visiting time: A tale of two prisons”, Probation Journal, Vol. 63 No. 3, pp. 347-361.

Jacobs, J.B. (1977), Stateville: The penitentiary in mass society, University of Chicago Press, Chicago, IL. 
Johnsen, B., Granheim, P.K. and Helgesen, J. (2011), “Exceptional prison conditions and the quality of prison life: Prison size and prison culture in Norwegian closed prisons”, European Journal of Criminology, Vol. 8 No. 6, pp. 515-529.

Kreager, D.A., Palmen, H., Dirkzwager, A.J. and Nieuwbeerta, P. (2016), “Doing your own time: Peer integration, aggression and mental health in Dutch male detainment facilities”, Social Science \& Medicine, Vol. 151, pp. 92-99.

Kruttschnitt, C. and Gartner, R. (2005), Marking time in the golden state: Women's imprisonment in California, Cambridge University Press, Cambridge.

Liebling, A., assisted by Arnold, H.(2004), Prisons and their moral performance: A study of values, quality and prison life. Oxford University Press, Oxford.

Liebling, A. (2011), "Distinctions and distinctiveness in the work of prison officers: Legitimacy and authority revisited”, European Journal of Criminology, Vol. 8 No. 6, pp. 484-499.

Liebling, A. and Ludlow, A. (2016), "Suicide, distress and the quality of prison life”, in Jewkes, Y. Crewe, B. and Bennett, J. (Eds.), Handbook on Prisons, Routledge, London, pp. 224-245.

Lindquist, C.H. (2000), “Social integration and mental well-being among jail inmates”, Sociological Forum, Vol. 15 No. 3, pp. 431-455.

Martos-Garcia, D., Devís-Devís, J. and Sparkes, A.C. (2009), "Sport and physical activity in a high security Spanish prison: An ethnographic study of multiple meanings”, Sport, Education and Society, Vol. 14 No. 1, pp. 77-96.

Maruna, S., Wilson, L. and Curran, K. (2006), "Why God is often found behind bars: Prison conversions and the crisis of self-narrative”, Research in Human Development, Vol. 3 No. 2-3, pp. 161-184.

McCorkle, R.C. (1993), "Fear of victimization and symptoms of psychopathology among prison inmates”, Journal of Offender Rehabilitation, Vol. 19 No.1-2, pp. 27-42.

McDougall, C., Pearson, D.A., Torgerson, D.J. and Garcia-Reyes, M. (2017), “The effect of digital technology on prisoner behavior and reoffending: A natural stepped-wedge design”, Journal of Experimental Criminology, Vol. 13 No. 4, pp. 455-482.

Meek, R. and Lewis, G. (2012), “The role of sport in promoting prisoner health”, International Journal of Prisoner Health, Vol. 8 No. 3/4, pp. 117-130.

Moerings, M. (2007), “Persistent offenders”, in Boone, M. and Moerings, M. (Eds.), Dutch prisons, BJu Legal Publishers, Den Haag, pp. 187-205 
Molleman, T. and Leeuw, F.L. (2012), “The influence of prison staff on inmate conditions: A multilevel approach to staff and inmate surveys”, European Journal on Criminal Policy and Research, Vol. 18 No. 2, pp. 217-233.

Molleman, T. and Van Ginneken, E.F.J.C. (2015), “A multilevel analysis of the relationship between cell sharing, staff-prisoner relationships, and prisoners' perceptions of prison quality”, International Journal of Offender Therapy and Comparative Criminology, Vol. 59 No. 10, pp. 1029-1046.

Pleggenkuhle, B., Huebner, B.M. and Summers, M. (2018), “Opting out: The role of identity, capital, and agency in prison visitation”, Justice Quarterly, Vol. 35 No. 4, pp. 726-749. Ross, M.W., Diamond, P.M., Liebling, A. and Saylor, W.G. (2008), "Measurement of prison social climate: A comparison of an inmate measure in England and the USA”, Punishment \& Society, Vol. 10 No. 4, pp. 447-474.

Ryan, R.M. and Deci, E.L. (2000), "Self-determination theory and the facilitation of intrinsic motivation, social development, and well-being”, American psychologist, Vol. 55 No. 1, pp. 68-78.

Ruiz, J.I. (2007), “Emotional climate in organizations: Applications in Latin American prisons”, Journal of Social Issues, Vol. 63 No. 2, pp. 289-306.

Schaefer, D.R., Bouchard, M., Young, J.T. and Kreager, D.A. (2017), “Friends in locked places: an investigation of prison inmate network structure”, Social Networks, Vol. 51, pp. 88-103.

Schalast, N. and Laan, J.M. (2017), "Measuring social climate in German prisons using the Essen climate evaluation schema”, The Prison Journal, Vol. 97 No. 2, pp. 166-180.

Shammas, V.L. (2014), “The pains of freedom: Assessing the ambiguity of Scandinavian penal exceptionalism on Norway’s Prison Island”, Punishment \& Society, Vol. 16 No. 1, pp. 104-123.

Sipma, F. and Soutendijk, D.A. (2016), Respons en implementatie van het medewerkerstevredenheidsonderzoek binnen Dienst Justitiële Inrichtingen (unpublished thesis). Universiteit van Amsterdam, Amsterdam.

Sparks, R., Bottoms, A.E. and Hay, W. (1996), Prisons and the Problem of Order, Clarendon Press, Oxford.

Stevens, A. (2012), Offender rehabilitation and therapeutic communities: Enabling change the TC way, Routledge, London.

Sykes, G.M. (1958), The society of captives: A study of a maximum security prison, Princeton University Press, Princeton, NJ. 
Tonkin, M. (2016), “A review of questionnaire measures for assessing the social climate in prisons and forensic psychiatric hospitals”, International Journal of Offender Therapy and Comparative Criminology, Vol. 60 No. 12, pp. 1376-1405.

Van der Helm, P., Stams, G.J., Van Genabeek, M. and Van der Laan, P. (2012), “Group climate, personality, and self-reported aggression in incarcerated male youth”, Journal of Forensic Psychiatry \& Psychology, Vol. 23 No. 1, pp. 23-39.

Van der Helm, P., Beunk, L., Stams, G.J., and Van der Laan, P. (2014), “The relationship between detention length, living group climate, coping, and treatment motivation among juvenile delinquents in a youth correctional facility”, The Prison Journal, Vol. 94 No. 2, pp. 260-275.

Van der Kaap-Deeder, J. et al. (2017), “Choosing when choices are limited: The role of perceived afforded choice and autonomy in prisoners' well-being”, Law and Human Behavior, Vol. 41 No. 6, pp. 567-578.

Van der Laan, A. and Eichelsheim, V. (2013), “Juvenile adaptation to imprisonment: Feelings of safety, autonomy and well-being, and behaviour in prison”, European Journal of Criminology, Vol. 10 No. 4, pp. 424-443.

Van Ginneken, E.F.J.C. (2016), “Making sense of imprisonment: Narratives of posttraumatic growth among female prisoners”, International Journal of Offender Therapy and Comparative Criminology, Vol. 60 No. 2, pp. 208-227.

Woessner, G. and Schwedler, A. (2014). “Correctional treatment of sexual and violent offenders: Therapeutic change, prison climate, and recidivism”, Criminal Justice and Behavior, Vol. 41 No. 7, pp. 862-879.

Wooldredge, J.D. (1999), “Inmate experiences and psychological well-being”, Criminal Justice and Behavior, Vol. 26 No. 2, pp. 235-250.

Wright, K.N. (1993), “Prison environment and behavioral outcomes”, Journal of Offender Rehabilitation, Vol. 20 No. 1-2, pp. 93-114.

Yang, S., Kadouri, A., Révah-Lévy, A., Mulvey, E.P. and Falissard, B. (2009), “Doing time: A qualitative study of long-term incarceration and the impact of mental illness”, International Journal of Law and Psychiatry, Vol. 32 No. 5, pp. 294-303. 
Figure 1: Sample selection

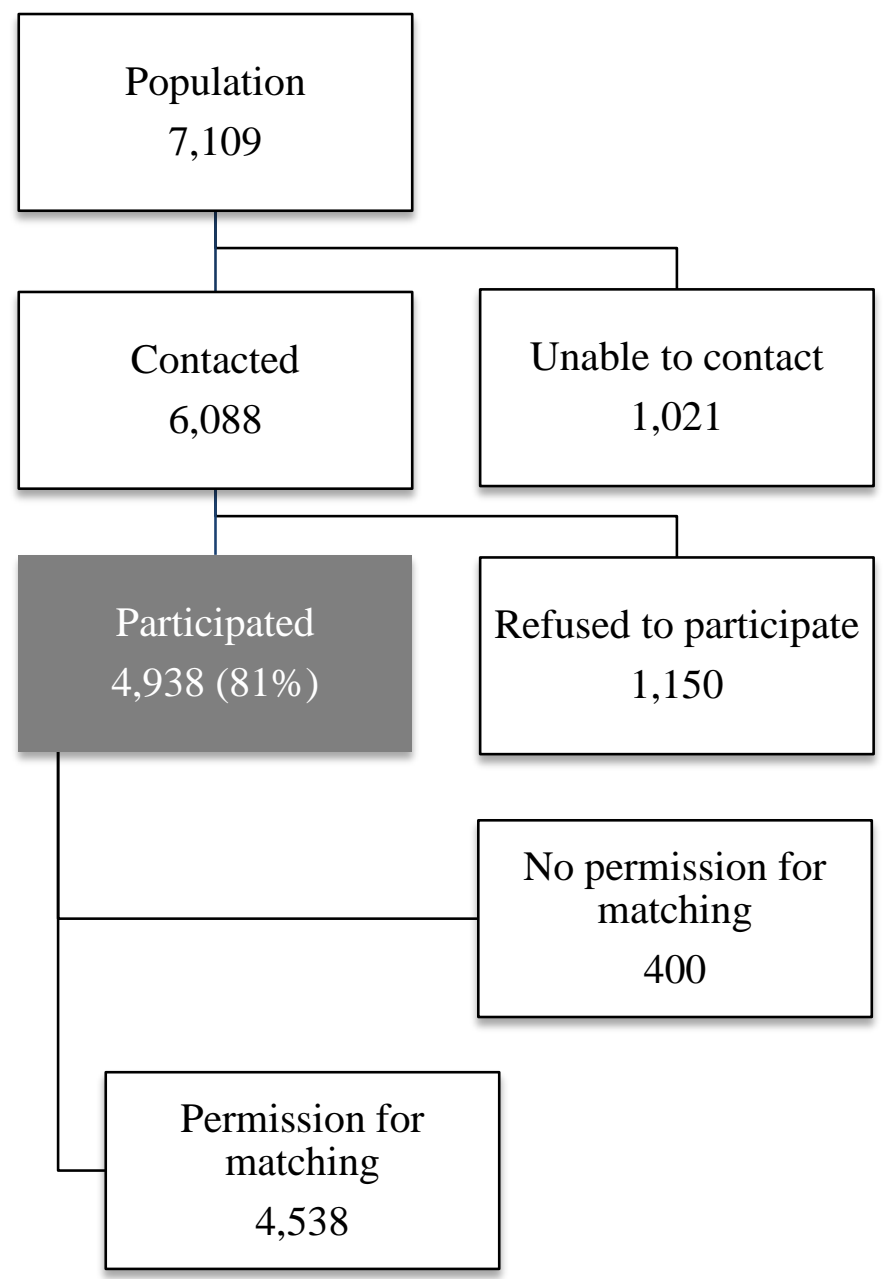


Figure 2: Mean scores on prison climate scales

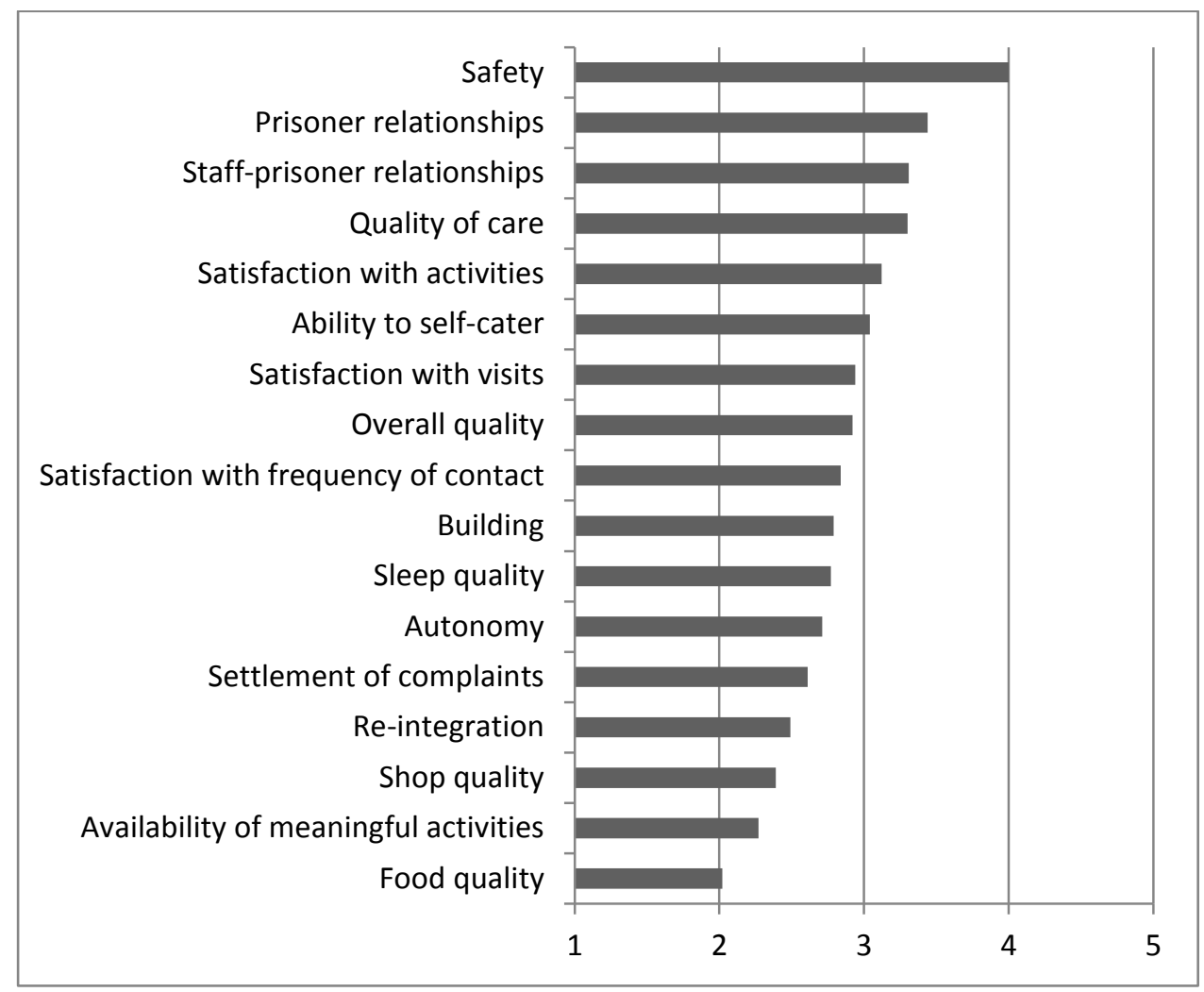


Table 1: Sample characteristics

\begin{tabular}{|c|c|c|c|c|c|c|}
\hline & \multicolumn{3}{|c|}{ Participants } & \multicolumn{3}{|c|}{ Non-participants } \\
\hline & $N$ & $\%$ & $M(S D)$ & $N$ & $\%$ & $M(S D)$ \\
\hline Age & 4538 & & $36.84(11.74)$ & 2284 & & $36.59(11.48)$ \\
\hline \multicolumn{7}{|l|}{ Sex } \\
\hline Male & 4288 & $94.6 \%$ & & 2179 & $95.4 \%$ & \\
\hline Female & 246 & $5.4 \%$ & & 104 & $4.6 \%$ & \\
\hline \multicolumn{7}{|l|}{ Country of birth } \\
\hline Netherlands & 2821 & $65.3 \%$ & & 1177 & $53.4 \% *$ & \\
\hline Netherlands Antilles & 312 & $7.2 \%$ & & 138 & $6.3 \%$ & \\
\hline Suriname & 188 & $4.3 \%$ & & 113 & $5.1 \%$ & \\
\hline Morocco & 154 & $3.6 \%$ & & 113 & $5.1 \% *$ & \\
\hline Turkey & 94 & $2.2 \%$ & & 51 & $2.3 \%$ & \\
\hline Poland & 79 & $1.8 \%$ & & 90 & $4.1 \% *$ & \\
\hline Other & 674 & $15.6 \%$ & & 521 & $23.7 \% *$ & \\
\hline \multicolumn{7}{|l|}{ Education } \\
\hline Low & 2297 & $56.1 \%$ & & & & \\
\hline Medium & 1272 & $31.0 \%$ & & & & \\
\hline High & 529 & $12.9 \%$ & & & & \\
\hline \multicolumn{7}{|l|}{ Offence } \\
\hline Violent & 1636 & $41.5 \%$ & & 762 & $41 \%$ & \\
\hline Property & 1189 & $30.2 \%$ & & 655 & $35.2 \% *$ & \\
\hline Drugs & 715 & $18.1 \%$ & & 263 & $14.1 \% *$ & \\
\hline Sex & 183 & $4.6 \%$ & & 73 & $3.9 \%$ & \\
\hline Other & 219 & $5.6 \%$ & & 107 & $5.8 \%$ & \\
\hline Time served (months) & 4536 & & $11.91(21.91)$ & 2247 & & $12.11(24.30)$ \\
\hline \multicolumn{7}{|l|}{ Children } \\
\hline No children & 1746 & $40.4 \%$ & & & & \\
\hline 1 or more children & 2574 & $59.6 \%$ & & & & \\
\hline \multicolumn{7}{|l|}{ Partner } \\
\hline Has partner & 2492 & $58.7 \%$ & & & & \\
\hline Has no partner & 1752 & $41.3 \%$ & & & & \\
\hline \multicolumn{7}{|l|}{ Regime } \\
\hline Pre-trial detention & 1728 & $38.1 \%$ & & 714 & $31.8 \% *$ & \\
\hline Prison & 1605 & $35.4 \%$ & & 940 & $41.9 \% *$ & \\
\hline Minimum-security & 217 & $4.8 \%$ & & 128 & $5.7 \%$ & \\
\hline Extra care & 274 & $6.0 \%$ & & 114 & $5.1 \%$ & \\
\hline Police detainees & 492 & $10.8 \%$ & & 227 & $10.1 \%$ & \\
\hline Persistent offenders & 220 & $4.9 \%$ & & 122 & $5.4 \%$ & \\
\hline \multicolumn{7}{|l|}{ Cell status } \\
\hline Single cell & 3353 & $78.7 \%$ & & & & \\
\hline Double cell & 910 & $21.3 \%$ & & & & \\
\hline
\end{tabular}

$* p<.05$. Results of chi-square tests and post-hoc tests comparing participants with non-participants, using adjusted standardised residuals. 
Table 2: Survey results for different regimes

\begin{tabular}{|c|c|c|c|c|c|c|c|}
\hline & $\begin{array}{c}\text { Total } \\
(N=4538)\end{array}$ & $\begin{array}{c}\text { Prison }^{a} \\
(n=1605)\end{array}$ & $\begin{array}{c}\text { Pre-trial }^{b} \\
(n=1728)\end{array}$ & $\begin{array}{c}\text { Police } \\
\text { detainees }^{c} \\
(n=492) \\
\end{array}$ & $\begin{array}{c}\text { Extra-care }^{d} \\
(n=274)\end{array}$ & $\begin{array}{c}\text { Persistent } \\
\text { offenders } \\
(n=220)\end{array}$ & $\begin{array}{c}\text { Min Security } \\
\quad(n=217)\end{array}$ \\
\hline \multicolumn{8}{|l|}{$\underline{\text { AUTONOMY }}$} \\
\hline Autonomy & 2.71 & $2.82^{b c f}$ & $2.54^{\mathrm{adf}}$ & $2.47^{\mathrm{adf}}$ & $2.90^{\mathrm{bcf}}$ & $2.69^{f}$ & $3.46^{\text {abcde }}$ \\
\hline \multicolumn{8}{|l|}{$\underline{\text { SAFETY AND ORDER }}$} \\
\hline Safety & 4.00 & $3.99^{\mathrm{df}}$ & $4.03^{\text {def }}$ & $4.01^{\mathrm{df}}$ & $3.78^{\mathrm{abcf}}$ & $3.82^{b f}$ & $4.35^{\text {abcde }}$ \\
\hline \multicolumn{8}{|l|}{$\underline{\text { RELATIONSHIPS IN PRISON }}$} \\
\hline Staff-prisoner relationships & 3.31 & $3.26^{\mathrm{df}}$ & $3.26^{\mathrm{df}}$ & $3.31^{\mathrm{df}}$ & $3.74^{\text {abce }}$ & $3.17^{\mathrm{df}}$ & $3.72^{\text {abce }}$ \\
\hline Prisoner relationships & 3.44 & $3.41^{\mathrm{ef}}$ & $3.46^{\mathrm{ef}}$ & $3.45^{\mathrm{ef}}$ & $3.45^{\text {ef }}$ & $3.10^{\mathrm{abcdf}}$ & $3.86^{\text {abcde }}$ \\
\hline \multicolumn{8}{|l|}{$\underline{\text { MEANINGFUL ACTIVITIES }}$} \\
\hline Satisfaction with activities & 3.12 & $3.22^{b c d}$ & $3.05^{\mathrm{acd}}$ & $2.78^{\text {abdef }}$ & $3.42^{\mathrm{abc}}$ & $3.20^{c}$ & $3.23^{c}$ \\
\hline Availability of meaningful activities & 2.27 & $2.39^{\mathrm{bcf}}$ & $2.14^{\text {adf }}$ & $2.01^{\text {adef }}$ & $2.49^{\mathrm{bcf}}$ & $2.24^{\mathrm{cf}}$ & $2.79^{\text {abcde }}$ \\
\hline Re-integration & 2.49 & $2.51^{\mathrm{cdf}}$ & $2.43^{\mathrm{cdf}}$ & $2.22^{\mathrm{abdf}}$ & $2.80^{\text {abcef }}$ & $2.41^{\mathrm{df}}$ & $3.18^{\text {abcde }}$ \\
\hline \multicolumn{8}{|l|}{ CONTACT WITH THE OUTSIDE WORLD } \\
\hline Satisfaction with visits & 2.94 & $3.05^{\mathrm{bc}}$ & $2.82^{\text {adf }}$ & $2.80^{\mathrm{adf}}$ & $3.14^{\mathrm{bc}}$ & 2.98 & $3.13^{\mathrm{bc}}$ \\
\hline Satisfaction with frequency of contact & 2.84 & $2.96^{\mathrm{bc}}$ & $2.71^{\text {acdef }}$ & $2.49^{\text {abdef }}$ & $3.03^{b c}$ & $3.00^{\mathrm{bc}}$ & $3.19^{\mathrm{bc}}$ \\
\hline \multicolumn{8}{|l|}{$\underline{\text { FACILITIES }}$} \\
\hline Sleep quality & 2.77 & $2.89^{b c f}$ & $2.68^{\mathrm{acf}}$ & $2.42^{\text {abdef }}$ & $2.72^{\mathrm{cf}}$ & $2.74^{\mathrm{cf}}$ & $3.40^{\text {abcde }}$ \\
\hline Food quality & 2.02 & $1.96^{\mathrm{cf}}$ & $1.93^{\mathrm{cf}}$ & $2.17^{\mathrm{abf}}$ & $2.07^{\mathrm{f}}$ & $1.88^{\mathrm{f}}$ & $2.91^{\text {abcde }}$ \\
\hline Shop quality & 2.39 & $2.21^{\text {bcdf }}$ & $2.46^{\mathrm{a}}$ & $2.60^{\mathrm{ae}}$ & $2.52^{\mathrm{a}}$ & $2.34^{\mathrm{cf}}$ & $2.65^{\mathrm{ae}}$ \\
\hline Building & 2.79 & $2.76^{\mathrm{f}}$ & $2.81^{\mathrm{f}}$ & $2.64^{\mathrm{df}}$ & $2.96^{\mathrm{ce}}$ & $2.60^{\mathrm{df}}$ & $3.20^{\mathrm{abce}}$ \\
\hline Ability to self-cater & 3.04 & $3.65^{\text {bcdf }}$ & $2.40^{\text {adef }}$ & $2.32^{\text {adef }}$ & $3.16^{\mathrm{abcf}}$ & $3.38^{b c f}$ & $4.54^{\text {abcde }}$ \\
\hline Settlement of complaints & 2.61 & 2.61 & 2.66 & 2.47 & 2.56 & 2.44 & 2.76 \\
\hline Quality of care & 3.30 & $3.24^{d}$ & $3.32^{\mathrm{d}}$ & $3.30^{\mathrm{d}}$ & $3.59^{\text {abce }}$ & $3.20^{\mathrm{d}}$ & 3.40 \\
\hline \multicolumn{8}{|l|}{$\underline{\text { OVERALL QUALITY }}$} \\
\hline Overall quality & 2.92 & $3.03^{\text {bcef }}$ & $2.83^{\mathrm{acdf}}$ & $2.58^{\mathrm{acdf}}$ & $3.20^{\text {bcef }}$ & $2.70^{\text {adf }}$ & $3.53^{\text {abcde }}$ \\
\hline \multicolumn{8}{|l|}{ WELL-BEING } \\
\hline Subjective well-being & 3.19 & $3.30^{\text {bdef }}$ & $3.07^{\mathrm{af}}$ & $3.21^{\mathrm{df}}$ & $2.93^{\text {acf }}$ & $3.06^{\mathrm{af}}$ & $3.71^{\text {abcde }}$ \\
\hline Psychological well-being & 3.81 & $3.92^{\text {bdf }}$ & $3.73^{\text {adf }}$ & $3.84^{\mathrm{df}}$ & $3.38^{\text {abcef }}$ & $3.74^{\mathrm{df}}$ & $4.24^{\text {abcde }}$ \\
\hline Subjective sentence severity & 3.48 & $3.44^{\text {bd }}$ & $3.57^{\text {acdef }}$ & $3.32^{\text {bd }}$ & $3.78^{\mathrm{abcef}}$ & $3.30^{\mathrm{bd}}$ & $3.27^{\text {bd }}$ \\
\hline \multicolumn{8}{|l|}{$\underline{\text { MISCONDUCT AND VICTIMISATION }}$} \\
\hline Self-reported misconduct in past 2 months & $26 \%$ & $27.8 \%$ cef & $24.9 \%{ }^{\text {ef }}$ & $18.9 \%{ }^{\text {ae }}$ & $28.1 \%{ }^{\mathrm{ef}}$ & $48.5 \%^{\mathrm{abcdf}}$ & $13 \%^{\text {abde }}$ \\
\hline Self-reported victimisation in past 2 months & $36 \%$ & $40.9 \%$ bcf & $34.5 \%$ acef & $26.3 \%$ abde & $43.9 \% \mathrm{cf}$ & $45.5 \%{ }^{\text {bcf }}$ & $21.2 \%^{\text {abde }}$ \\
\hline Ever felt discriminated against? & $19 \%$ & $24.3 \%{ }^{b c f}$ & $17.4 \%{ }^{\text {acf }}$ & $10.2 \%$ abde & $21.7 \% \mathrm{cf}$ & $25.4 \%{ }^{b c f}$ & $6.6 \%$ abde \\
\hline
\end{tabular}

N.B. Means with different superscripts for a regime are significantly different at $p<.05$ 